\title{
The Arguments for a Specialist Employment Court in New Zealand
}

\section{Bernard Robertson *}

This paper is concerned with the issue of the structure of the employment institutions. The author argues that, if it is agreed that the present position is illogical and incoherent, the question is which way should New Zealand move? Should a more specialised and autonomous employment law system be created with its own appeals or should the Employment Court be abolished? In attempting to answer that question he explores the arguments for having specialist employment institutions. In doing so the paper attempts to show that the existence of a specialist Court is inconsistent with an employment régime based on free contracting.

\section{Introduction}

There seems to be consensus amongst all who consider the matter, that the Employment Contracts Act 1991 (ECA) is philosophically incoherent. Both Maryan Street (1993), former President of the New Zealand Labour Party, and Ruth Richardson (1995: 226), former National Party Finance Minister, agree in labelling the early Parts of the Act, based on a philosophy of free contracting, as inconsistent with Part VI which creates the specialist institutions. Other writers on employment law in New Zealand agree (Walsh and Ryan, 1993: $18)$.

A notable exception is the present government which appears content to leave the current arrangements until it can be seen "how well they are working"(Bradford, 1993). Since no specified outputs are required of the Employment Court, there is no way of telling "how well it is working".

There is also general agreement that the current jurisdictional divide between the Employment Court and the High Court is impractical and undesirable. Chief Judge Goddard has pointed out that the current rules potentially "expose the same defendant to litigation at the suit of the same plaintiff in respect of the same subject matter in two different Courts", than which, His Honour said "nothing could be more undesirable or more disgraceful"(1993). On the other side of the divide Hammond $\mathrm{J}$ has referred to the current position as being redolent of the old forms of action. ${ }^{1}$

* $\quad$ Editor, New Zealand Law Journal. The research and writing of this paper was supported by the New Zealand Business Roundtable and thanks are due to numerous commentators. The author is entirely responsible for the views expressed and any errors made.

Laser Alignment (NZ) 1984 Ltd v Scholz [1993] 2 ERNZ 250 (HC). 
The role of the Court of Appeal is seen as anomalous. Appeals from the Employment Court go to the Court of Appeal which is hence likely to retain a "controlling influence on the development of employment law" (Homewood, 1993). The Court of Appeal also has the power of judicial review of the Employment Court. This casts doubt on the rationale for a separate Employment Court. A leading role in the development of employment law is held by a Court none of whose members have been Employment Court Judges. Conversely, if the Court of Appeal is capable of dealing with employment cases on appeal it is difficult to see why the High Court is not capable of dealing with them at first instance.

If it is agreed that the present position is illogical and incoherent, the real question is which way should New Zealand move? Should a more specialised and autonomous employment law system be created with its own appeals or should the Employment Court be abolished? In order to answer that question it is necessary to explore the arguments for having specialist employment institutions. In doing so this paper will show that the existence of a specialist Court is inconsistent with an employment régime based on free contracting.

\section{Officials' Committee arguments}

In 1990 the new National Party government intended to legislate immediately to reform the substantive law of employment but to leave institutional questions to a later date. It became clear, however, that these matters could not be disentangled and so the government decided to deal with both issues in the one Bill.

On the institutional issues however the government had no clear policy and indeed, no apparent grasp of the issues. Consultation took place and an Interdepartmental Officials' Committee (1991), including the Labour Department, called for the retention of specialist institutions on the grounds of expertise, flexibility, avoidance of legalism and preservation of Parliament's intentions. Other defences of a separate labour court system are available. At the most theoretical these include a claim of autonomy on behalf of labour law, at the least theoretical that the Employment Court is cheaper and more "user-friendly" than the High Court. It is also argued that the Employment Court is not as "bad" as it is painted, that its critics have misrepresented its behaviour in various ways. These arguments will now be considered.

\section{Expertise}

The main point made by the Officials' Committee under this heading was the on-going nature of the employment relationship. The Committee said that the

average occupants of the judicial bench are more used to dealing with one-off settlements, derived from the application of abstract principles embodied in precedents, and have little knowledge of the realities of the workplace and the on-going nature of the employment relationship.

The same comment could, of course, be made about almost any aspect of business. It seems that the Officials were thinking about the problems of daily life rather than the settlement of 
disputes in court. Employment may generally be an on-going relationship but that does not mean that disputes before the Employment Court concern relationships that are actually subsisting at the time of the hearing. Many, if not most, concern relationships which have already ended. The purpose of the dispute is to reallocate the losses caused by the relationship ending in a way other than that originally intended. No evidence is offered by the protagonists that Employment Court Judges deal predominantly with on-going relationships. $^{2}$

Even if it were true, this problem is not peculiar to employment contracts. Long-term and subsisting contracts pose different questions from those raised by more short-lived contracts. Wholesale energy contracts are a case in point (McNeil, 1978; Gaines, 1995). In these cases the Judges are dealing with contracts which will survive the litigation, but it is High Court Judges who have to do it.

The "expertise" argument assumes either that there is something to be expert in or that some special skill is required. The first raises the question of the autonomy of labour law, which is discussed below. Employment cases can raise questions in contract, tort, equity, restitution, public law and even criminal law. It seems then that Employment Court Judges, far from being experts in a narrow area, have to have an understanding of the whole seamless web of the law, as do High Court Judges.

The second idea is reflected in comments such as Vranken's:

The major factor which triggers the need for labour courts rather than the courts of general jurisdiction is that judges of a specialist court, because of their expertise and background in the subject, are most likely to demonstrate the sensitivity required when dealing with labour disputes. (1988: 497)

Since Employment Court Judges do not negotiate agreements but decide disputes, it is unclear why "sensitivity" beyond that required of a High Court Judge is a pre-requisite. Whatever the reason, this prediction does not seem to have been borne out, at least in the eyes of the Court of Appeal which in one case went so far as to remark that "the manner in which the Employment Court's judgment was expressed could only have exacerbated the situation." ${ }^{3}$

Expertise is often said to include knowledge of "custom and practice". This is an interesting argument. Other areas of law draw on "custom and practice". Classical contract law grew up in this way; indeed Hayek's evolutionary theory claims that the entire common law grew up in this way. In these other areas of law judges are informed as to "custom and practice" by counsel and witnesses. This imposes costs where the same matter is explained to a succession of judges, but eventually a custom or practice becomes the subject of judicial notice or part

2 This would have been a natural assumption when cases were between unions and employers. There was then a long term relationship, the union effectively acting as a seller of labour and the employer as purchaser from the union rather than from the employees themselves.

3 Capital Coast Health Ltd v NZ Medical Laboratory Workers Union Inc 1996] 1 NZLR 7, 9 per Hardie Boys J. 
of the law. Where this is not so the parties may wish to argue a point rather than let it be taken into account by a judge sub silentio. The "custom and practice" argument is also inconsistent with the views, discussed below, that the role of employment law is to change practice, to impose a commanded structure against the wishes of the parties.

There is no requirement in the ECA for any particular experience other than seven years practice of law. ${ }^{4}$ There seems to be no practical requirement for any particular experience. Of the original judges, two were formerly District Court Judges with Family Court warrants, so presumably had experience of dealing with the breakdown of long-term relationships. Two were employment lawyers (crudely speaking one employers' lawyer and one trade union lawyer) and two were in general practice. The Chief Judge was mainly known as a defamation expert. ${ }^{5}$

All these points undermine the expertise argument, but the major point against it is the haphazard nature of the jurisdictional divide between the Employment Court and the High Court. Over the last 100 years matters have moved into and out of the competence of the specialist employment institutions (Fulton, 1987). The ECA swept away much of the jurisdiction of the Labour Court and replaced it with matters previously the preserve of the High Court. In fact it could be said that in 1990 Employment Court Judges had no experience of settling disputes relating to individual employment contracts, whereas High Court Judges did. ${ }^{6}$

Not only has there been no rational allocation of functions over time but the present boundary lines are incoherent. Current jurisdictional disputes are notorious; many issues arise in the High Court which closely resemble employment law matters. Even if it were true therefore that employment law were an autonomous branch of the law, the boundary lines drawn by Parliament have always left and still leave to the High Court many issues in which the Employment Court is supposedly expert.

The greatest of these boundary problems is caused by the distinction between contractors and employees. Two people working under nearly the same conditions can find their affairs regulated by entirely different procedural and substantive law. The anomalies that this causes have led to calls for contractors, or at least "dependent contractors" to be brought under the Employment Contracts Act. ${ }^{7}$ The difficulty is that wherever the boundary line is drawn, new

4 s. $113(2) \mathrm{ECA}$

5 It is all very well to talk about a "mix of appropriate experiences" but most EC cases will be heard only by one judge.

6 Although the Labour Court dealt with personal grievances this procedure only applied to the 40 percent of the labour force covered by collective employment contracts until the ECA extended the procedure to individual contracts. Only a union could bring a personal grievance action as of right; even an individual covered by a collective agreement could not bring a personal grievance action without leave fo the Court, s.218 Labour Relations Act 1987.

7 Goddard (1996) defined a "dependent contractor" as one with only one client "often prohibited by or under their contract from having any others". 
anomalies will arise. People will arrange their affairs so as to fall just outside the definition of a "dependent contractor" and there will be further calls for the Act to be extended to cover new ranges of circumstances. The situation is unstable and cannot be made less so by altering the definitions.

\section{Flexibility}

The Officials' Committee believed it important that employment law operate in a flexible fashion; that parties were encouraged to settle disputes without going to court and to use nonlegal mediators. This view is mirrored by Maryan Street who observes that employment disputes should be resolved, not won or lost (Street, 1993).

This is not an argument about employment law, but about law and the legal system. There are thousands of differences between people every day which do not even go near lawyers. If they go to lawyers the bulk are settled informally or formally without going to court. This is achieved without any intervention by the state, save that the ordinary Courts encourage these activities by a variety of devices. In the case of the ECA settlement of disputes by alternative means is specifically provided for by section $3(2)$.

There seem to be two possible explanations for this argument. One is an underlying belief that all disputes of a legal nature go to court where they are dealt with in the formalistic manner of a court case. The other is a belief that organs of state must be involved at an early stage in employment disputes, if not in other disputes. Institutions must therefore be fashioned which can achieve sensitive resolution of differences.

The first of these ideas is clearly mistaken. The second would seem to be a conclusion requiring argument rather than a starting-point. Even if it were true however, this is irrelevant to the nature of the Employment Court. Cases that reach the Employment Court are the equivalent of the cases in other areas which reach the Courts, other methods of resolution having been tried or rejected. The desirability of informal settlements says nothing about how disputes not suitable for such resolution are to be dealt with and is not a reason for having a specialist Court. In fact, this argument conflicts with the supposed advantage of the cheapness and accessibility of the Employment Court since that feature might be expected to encourage more people to take their cases to the Court rather than to allow them to be settled informally.

The Officials' Committee hoped to avoid rigid following of precedent. This raises questions about the nature of law and how people are to order their affairs if they cannot tell in advance what the attitude of the Court is to be. It demonstrates a failure on the part of the Officials to understand the distinction between officials who implement policy and judges who decide disputed questions of law. Suffice to say however, that the position of precedent in the Employment Court is in theory exactly the same as in the High Court. That is to say that a previous decision of the Court is not formally binding on it but Judges will usually require 
some good reason or argument for departing from it. ${ }^{8}$ On the other hand, decisions of the Court of Appeal are binding on the Employment Court, as on the High Court. There is obviously substantial variation between Judges of all Courts as to their willingness to depart from their brethren's judgments. Even if the Employment Court adopted some radical approach to its own precedents it would still be bound by decisions of the Court of Appeal, which could include decisions on the role of precedent in the Employment Court. It is difficult to see how the Officials' Committee could have expected the position to be any different.

Much of this discourse ignores (perhaps deliberately) fundamental insights of the economic model. Coase' Theorem tells us that regardless of the legal position rights will end up in the hands of those who value them most. ${ }^{9}$ A court case is thus a prelude to bargaining, rather than an alternative to it. For exchange to be free, however, rights must be clearly defined. Where rights are not clearly defined recourse to a Court is necessary to obtain a clear definition. Resolution of the practical problem in the real world can then proceed, informed by knowledge of where the legal rights lie. An Employment Court case then, is not or should not be aimed at resolving a dispute in the real world. It should be aimed merely at allocating legal rights so that the parties may then resolve their dispute in an atmosphere of some certainty as to the value of the rights they are trading.

\section{Avoidance of Legalism $\sqrt{ }$}

The Employment Court has been criticised for excessive legalism, even by the Court of Appeal, ${ }^{10}$ a fact which renders ironical the Officials' Committee view that a separate Employment Court would avoid this vice.

It is not entirely clear what is expected from a Court, if not legalism. But whatever answer is given will be an argument not about labour law but about the nature and role of the legal system. If there is something accurately described as "excessive legalism" there does not seem any good reason why other parts of the legal system should suffer it.

This is therefore not an argument in favour of having a separate Employment Court. It is either an argument for reforming (or perhaps abolishing) the entire legal system, or it is an argument for exempting employment matters from legal control at all.

This line of reasoning also places the Employment Court in a difficult position. If it does what the Officials' Committee would doubtless describe as "avoiding excessive legalism" it

8 Per Chief Judge Goddard Central Clerical etc IUW v Victoria University Students Association [1990] 2 NZILR 294 and NZPSA v Electricity Corp of NZ Ltd [1991] 1 ERNZ 610.

9 Although trade is not entirely free under the ECA. Employees have numerous terms imposed by law, such as public holidays, dismissal for cause etc. which they are not free to trade away.

10 Capital Coast Health Ltd v NZ Medical Laboratory Workers Union Inc [1996] 1 NZLR 7, 18 "it is not appropriate to subject [the ECA] to esoteric analysis or to draw fine distinctions in its application" per Hardie-Boys J. 
will be criticised for unpredictability, bias and excessive activism. If it does not then it calls into question its raison d' être.

\section{Parliament's intentions}

The Officials' Committee suggested that the common law would fail to take account of equity issues and imbalance of power between contracting parties. There are a number of responses to this. The first is to say that this is a matter to be addressed by the statute. Once it has been there is no reason why a special court should be required to implement the law. The only reason for having a special court on this argument is that one wants the judges to implement a policy and to pursue a social goal rather than to apply the words of an Act of Parliament. In that case traditional concepts of the rule of law and the role of judges are clearly being departed from. In particular it will be necessary to select the judges carefully to ensure that they will in fact pursue this social programme.

Secondly the argument reveals a particular political viewpoint. It has been demonstrated over and over again that "inequality of bargaining power" is a canard. What matters is the competitiveness of the market. This viewpoint disregards the mutually beneficial nature of voluntary contracting and is in direct contradiction to the general philosophy of the Employment Contracts Act. Like most arguments about state intervention in employment bargaining, this argument does not explain why contracts of employment are regulated when contracts for services are not. If the inequality of bargaining power argument were correct it would obviously apply to contractors as much as to employees.

Finally, it may be observed that there is a certain irony in this argument since it is precisely the contention of the Business Roundtable and others that the one thing the Employment Court has not been doing in its decisions on substantive employment law is giving effect to the will of Parliament (Howard, 1995; Richardson, 1995: 89)

The Officials' Committee also argued that contract law is not homogeneous and that special arrangements exist in other areas. It cited the examples of the Family Court, Fair Trading Act and Tenancy Tribunals. Walsh and Ryan (1993: 26) believe this a powerful argument, undermining the claim that specialist jurisdiction for labour law would be anomalous. It is not.

Most contracts today are regulated by legislation which either amends or replaces the common law. The High Court nonetheless enforces them, including the Fair Trading Act. The Family Court is a part of the District Court and its judges are District Court Judges specially selected for that work, but who continue to deal with ordinary District Court business. Tenancy Tribunals are indeed state organs created to deal with private disputes, but their status is that of administrative tribunals, heavily regulated by the High Court and entirely lacking the status of the Employment Court.

More than anything else, these arguments demonstrate that the Officials' Committee (and Walsh and Ryan) lacked any real understanding of (or perhaps sympathy for) the nature and working of the ordinary legal system. 


\section{Others' arguments}

\section{Employment Court not so bad}

It is argued that the Employment Court is not so bad as it is made out to be and is not out on a jurisprudential limb: that contract law outside the employment field is developing away from the freedom of contract model and that the Employment Court does make decisions in favour of employers.

Thus Anderson (1993b) says that the "new right" arguments assume that the "ordinary courts" apply classical contract theory and ignore the extent to which contract law is moving away from classical positions. It is also argued that the Court of Appeal in decisions such as Brighouse Ltd $v$ Bilderbeck ${ }^{11}$ merely applied to employment law the same principles that it has applied to contract law generally (Russell, 1995). Two points can be made in reply. One is that the New Zealand Business Roundtable has also criticised these developments in contract law. ${ }^{12}$ That body at least is well aware of these developments and its criticism of Employment Court decisions is entirely consistent with its criticism of judicial activism in the private law field generally. The second obvious rejoinder to this argument is that it is hard to see the necessity for a separate Employment Court if the ordinary Courts are not going to implement the classical contractual doctrines that Anderson and others are anxious not to see imported into employment law.

The second of these arguments is that the Employment Court demonstrates its impartiality and professionalism by making decisions in favour of employers. Examples cited in support of this argument by Wilson (1993) include Adams $v$ Alliance Textiles ${ }^{13}$ Hawtin $v$ Skellerup International ${ }^{14}$ and Emergicare (Henderson) Ltd $v$ NZ Nurses Union. ${ }^{15}$ Here again the Employment Court seems to be in a bind. If it appears to act in favour of employees it will be accused of partiality, favouritism and over-activism. If it acts without fear or favour to interpret pre-existing law then the Employment Court is failing to serve the purposes its proponents wish it to serve. It also fails to establish a case for its continued existence, since its product is not differentiated from that of the High Court.

11 [1995] 1 NZLR 158; [1994] 2 ERNZ 243 (CA)

12 For example, in Appeals to the Privy Council Submission to the Attorney-General by the New Zealand Business Roundtable July 1995.

${ }^{13}$ [1992] 1 ERNZ 982

14 [1992] 2 ERNZ 500

15 [1991] 2 ERNZ 583 


\section{Special appointments}

It is difficult to resist the conclusion that the real agenda behind the arguments of many proponents of a separate Employment Court is that revealed by Maryan Street as "The Labour Party's view". Street's argument is based on a world-view which she attributes to William Pember Reeves, but which is in fact straight Marxist analysis. That is that the world is made up of different classes of people with opposing interests and that the role of the state is to stabilise the relationships between these classes. Employment law is one of the devices by which this is done.

Street also mentions the common law's antipathy to combinations (on both sides of the employment divide). It is implicit in these arguments that it is not enough to have a separate Employment Court; it must consist of judges who share Street's views rather than the traditional views of the legal system, a point consistently made in the legal literature (Wedderburn, 1989; Hepple, 1988). The role of the judges is to pursue an agenda which for some reason is not set out in the legislation. This is entirely opposed to traditional legal values and also to the philosophy of the government and the remainder of the ECA.

Attempts to predict the decisions of judges once appointed to the Bench are notoriously difficult, especially when they are protected by security of tenure. Such attempts are, however, much more likely to be successful when there are only six judges in a court which deals only with disputes drawn from one area of life. Furthermore, Street's rationale for the Court is dependent not on technical legal opinion but on a world view. It should be relatively easy to detect lawyers who share that world view.

The precedent of a specialist Court having been set, the government could obviously side-line any judge who did not make the right decisions by creating specialist courts to deal with subdivisions of employment law and reassigning the judges. However the logic of Street's argument is that tenure should be done away with, so that judges who do not pursue the agenda they were appointed to pursue can be dismissed.

Street's arguments are essentially a muted call for the triumph of socialism over law. They constitute an attack on the whole concept of the independence of the judiciary and the rule of law. It is alarming to find such views expressed by the President of a mainstream political party. The National Party appears completely to have failed to grasp these arguments of fundamental principle. It is submitted that the threat to fundamental legal values represented by Street's paper alone provides compelling reasons for abolishing the Employment Court before a Labour government can come to power.

Given the public expression of such views the position of the Employment Court after the next general election will very difficult. Should a Labour/Alliance government be returned then on every occasion in which the Employment Court appears to exhibit "activism" on behalf of employees, it will be accused of taking advantage of political backing to implement its own programme, or of implementing the government's programme ahead of legislation. If, on the other hand, a National/ACT Coalition were to be in office then at every sign of "even-handedness" the Court would be accused by unions of being timid in an attempt to stave off abolition. The Employment Court is thus hopelessly and irretrievably politicised. 
The longer this situation were allowed to last the greater the chance that these attitudes would be carried over into criticism of the ordinary courts.

\section{Cheapness/Informality of Employment Court}

The Employment Court is said to be much cheaper and more "user-friendly" than the High Court. In particular a party may be represented by a lay employment advocate, rather than by counsel. ${ }^{16}$ The Court's fees are low compared to the High Court. If the Court were to be abolished, however, many employment disputes would come within the jurisdiction of the District Court and the Disputes Tribunal, so comparison with the High Court only may be inappropriate. Furthermore, this argument should not be taken without question. The efficiency of Courts is extremely difficult to measure and anecdotal evidence suggests that hearings in the Employment Court may be lengthier than equivalent cases in the District Court. Where cases are dealt with more speedily this may be because the Court is more generously resourced for its case-load than are the ordinary Courts.

Whatever conclusion may be drawn from this however, it is not that a Court with exclusive jurisdiction is required. Indeed, given exclusive jurisdiction one would expect the Court to exploit its monopoly position, if only to the extent of resting on its laurels, so that its competitive advantage disappeared.

A plaintiff is entitled to file in any Court that has jurisdiction over the matter. It is for the defendant to argue that the jurisdiction chosen is not the appropriate or convenient one. If it is the case that the Employment Court is attractive to plaintiffs on the grounds of cheapness and informality, there is no need for an exclusive jurisdiction. In fact it would be better not to have an exclusive jurisdiction, so that the Employment Court was encouraged to maintain these desirable characteristics.

There is today concurrent jurisdiction and effective competition between the Employment Court and the High Court over many issues. The issue of overtly competitive provision of court services has recently been raised and regarded as highly controversial. ${ }^{17}$ Throughout the seventeenth and eighteenth centuries however, this was the effective position. The Courts of King's Bench, Common Pleas and Exchequer Chamber were in competition with one another for the marginal business. As one of these courts became expensive and procedurally cumbersome so the others would expand their own jurisdiction to take some of the business (Elton, 1960). Concurrent jurisdictions are arguably in the users' interests, provided that once an action is under way in one jurisdiction related actions can be prevented from being run in other jurisdictions.

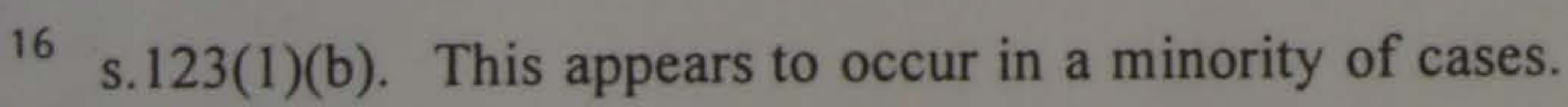

17 See contributions by Wiggs, Law Talk, No 431: 38 (April 1995) and Bridgman Law Talk No 434: 17 (May 1995). 
The other conclusion from the observation that the Employment Court is cheaper and more "user-friendly" than the High Court is that the latter Court should change its procedures. State monopolies seldom alter their procedures to become more useful to the customer without the stimulus of competition. Such a stimulus is presented by commercial arbitration and the High Court has responded by setting up the Commercial List. ${ }^{18}$ In general however, as is customary with state monopolies, the reaction to backlogs of work is to agitate for an increase in inputs rather than to examine the efficiency with which the system works. ${ }^{19}$

For present purposes the key point is that if it is true that it is advantageous to parties to use the Employment Court, there is no need for a rule giving exclusive jurisdiction, in fact such a rule may be counter-productive.

\section{Autonomy of Labour Law}

The intellectual core of this argument is the claim for autonomy made on behalf of employment law. In traditional terms "employment law" is not a conceptual subdivision of "law" as are public law, the law of property, the law of obligations and criminal law. Each of these consists of a series of abstract principles. Like family law, maritime law, and many other subjects, employment law is a contextually defined subject. Its defining characteristic is the subject matter to which principles and rules drawn from various conceptual subdivisions of law are applied, namely the employment relationship.

Claims by academics and practitioners that their area of speciality should be recognised as an "autonomous area of law" are neither rare nor surprising. One is entirely free to interest oneself in whatever one wishes and even to design courses in such contextually defined subjects. These should be studied after the main conceptual divisions of the law have been absorbed. The concept of "autonomy" is not self-defining however. Nor is it clear what consequences follow from a claim for autonomy. Rather than concentrate on the idea of "autonomy" therefore, it seems more profitable to identify what is actually being said about employment law and to examine each of these points in turn.

Employment Law not just part of Contract: The first claim frequently met is that employment law is not just a subdivision of the law of contract. This is obviously true. The relations between an employer and employee may involve questions of contract, tort, equity, public, property and even criminal law. Judges dealing with employment law questions therefore need to be versed in all these areas of law, as do judges of the ordinary courts. The real issue is whether applicable rules and principles are to be "developed" in the context of employment cases consistently with, or in isolation from, their parent areas of law.

When the fact that employment law is not merely a subdivision of contract law is deployed as an argument it really seems to be a denial that employment contracts are ruled by classical contract theory. This again is undeniable. It does not lead to the conclusion that there must

18 s.24A Judicature Act 1908

19 The number of High Court and Court of Appeal Judges has in 1995 been raised to 38 . 
be a separate court to deal with these issues. Almost no contracts in New Zealand today are governed entirely by the common law of contract, let alone by classical contract theory. Legislation such as the Contractual Mistakes Act has created new causes of action and new remedies. The ordinary courts administer these Acts and, as discussed above, have clearly departed from classical contract theory even at common law.

Employment Contracts are governed by specific legislation: Numerous different kinds of contract are governed by specific legislation. Motor vehicle securities, sales of land, international carriage of goods and others too numerous to mention are governed by their own Acts. These are all administered by the ordinary courts.

Employment Contracts are different: This is a diffuse argument because any phenomenon can be described as different from, or similar to any other phenomenon, depending upon the characteristics chosen for comparison. The complexity and enduring nature of employment contracts has already been discussed. The key argument that employment contracts are different seems to be a statement that:

a contract to buy and sell labour is fundamentally and essentially different from any other commercial contract. Human labour "cannot be separated from its source" (Street, 1993).

Sir Ivor Richardson has said, "people are not commodities and the performance of services is not akin to the supply of goods." 20

To see that this is not so one only has to consider contracts for the manufacture and sale of some item like hand-made chairs. If a customer in a craft shop sees a beautifully made chair and buys it, that is certainly a contract for sale. If the customer asks for a second one to be made, is that a contract for sale or for services? And if the former, why is a contract to produce a research paper or a legal manual a contract for services? It is also unclear why any arguments about "the dignity of human labour" apply only, for example, to the relationship between a restaurant owner and a waiter and not between the customer and the restaurant.

Secondly, contracts of all sorts can affect livelihoods. The reason a company may make staff redundant may be that it has lost, or failed to renew a contract. To protect workers from the capricious effects of contractual freedom therefore, state intervention needs to be on a far broader band than employment contracts.

But two more fundamental points render these statements unhelpful under present circumstances. The first is the fact that employment law applies only to employees and not to contractors. It is submitted that the distinction between employees and contractors is entirely inconsistent with the idea that employment law exists to protect some fundamental human value. This argument is, if anything, a programmatic one; it is an argument for the extension of employment law to contracts for services and that is indeed how we find it being used by many. It is therefore disappointing to find some who would cavil at that major inroad into individual autonomy falling for the "employment contracts are different" argument. 
Most fundamentally of all however, this argument entirely misconstrues ordinary contracts of sale. We do not trade commodities, we trade rights. A contract of service or of services is essentially a trading of the rights to the fruits of an individual's labour. This trade will be made for the same reason that any other trade is made, namely that in the hands of the buyer the labour is worth more than in the hands of the seller. This may be because certain tasks require the organisation of a number of people, or because the buyer of labour has ideas, knowledge or access to capital that the seller of labour does not have.

The employment relationship: the end of the autonomy argument is the proposition that employment should be regulated not by contract (and other aspects of private law) but by a legal "employment relationship" which would be regulated public-law style. This is based on the idea that employment is not a mutually beneficial relationship based on a free transaction but upon "subordination" (Wedderburn, 1989), "subservience" (Goddard, 1996) or "economic dependence and social subordination" (Wedderburn, 1989; Collins, 1990; Goddard, 1996). It therefore needs to be regulated, not to ensure that the wishes of the parties are properly enforced but to ensure that social policies determined by the legislature are imposed on possibly unwilling parties.

In so far as the expertise argument depends upon "custom and practice" these arguments actually conflict. The supporters of an autonomous labour law do not want the Courts to enforce the custom and practice of the parties; they want to change practice by enforcing legislatively mandated social policies. That is to say that the autonomy of labour law is espoused for the purpose of achieving a change of view on the part of the courts. The aim is to correct a perceived imbalance of power which the ordinary law will not correct. The rhetoric of autonomy refers to the need to "cut adrift from the rules and methods of civil law which prejudice workers" (Wedderburn, 1989: 234). There is a clear assumption in much labour law writing that the measure of success of any employment law institution is how sympathetic it is to the interests of "workers" (e.g. Hepple, 1988). This is bound to leave one wondering whether the "expertise" desired is actually expert knowledge of social policy rather than of "the realities of the workplace".

In short this argument is a manifestation of the belief that equal application of rules of law will perpetuate the subjection of the "workers" and protect the interests of the monied classes. It is surprising therefore, to find defenders of the Employment Court responding to criticism of it on the grounds that such criticism endangers the independence of the judiciary: the arguments for a separate employment court clearly stem from a philosophy hostile to that concept. Anderson commented on recent criticism of the Employment Court by saying:

The suggestion by influential political groups, that a Court should be abolished because its decisions do not fully reflect the ideology and interests of that group, goes beyond the bounds of justifiable criticism. (Anderson, 1993a: 90)

But it is clear that the main reason for having a separate employment court is that certain influential political groups believe that High Court Judges cannot be relied upon to make decisions fully reflecting their ideology and interests.

The ECA is motivated by the belief that individuals will best flourish and advance their own interests when they are free to define those interests for themselves and pursue them as they 
see fit. The autonomy argument is an argument for unequal treatment and for the use of the law as an instrument for the implementation of social policy. Either the Employment Court behaves in this way, in which case its survival is entirely inconsistent with the philosophy of the substantive law of the ECA, or it behaves like an ordinary Court in which case its survival is pointless.

\section{References}

A Specialist Employment Law Jurisdiction (1993), Proceedings of a Seminar, New Zealand Institute of Industrial Relations Research, Wellington.

Anderson, G. (1993a), The Judiciary, The Courts and Appeals, Employment Law Bulletin, 9091.

Anderson, G. (1993b), Specialist Employment Law and Specialist Institutions. In A Specialist Employment Law Jurisdiction.

Bradford, M. (1993), The Future of the Employment Court and Tribunal: The Government View. In A Specialist Employment Law Jurisdiction.

Collins, H. (1990), Independent Contractors and the Challenge of Vertical Disintegration to Employment Protection Laws, Oxford Journal of Legal Studies, 10: 353-380.

Elton, G. (1960), The Tudor Constitution, Cambridge University Press.

Fulton, H. (1987), The New Labour Court: Window Dressing or Substantive Change, New Zealand Law Society Conference Papers, 145.

Gaines, S. (1995), Long Run Contracts, Classical Doctrines and Economic Efficiency, Law and Economics Conference, Lincoln University.

Goddard, T.G. (1993), The Role of the Employment Court. In A Specialist Employment Law Jurisdiction.

Goddard, T.G. (1996), Employment Law and Specialist Employment Institutions in Prospect. In Proceedings of the 25th Anniversary Seminar of the of the Industrial Relations Centre, Victoria University of Wellington.

Harbridge, R. (1993), Employment Contracts: New Zealand Experiences, Wellington, Victoria University of Wellington Press.

Hepple, B. (1988), Labour Courts: some comparative perspectives, Current Legal Problems, 169-196. 
Homewood, S. (1993), Decision Making Trends in the Court and Tribunal. In A Specialist Employment Law Jurisdiction.

Howard, C. (1995), Interpretation of the Employment Contracts Act 1991, Wellington: NZ Business Roundtable.

Interdepartmental Officials Committee (1991), Employment Contracts Bill: Outstanding Policy Issues.

McNeil I. (1978), Contracts: Adjustment of Long Term Economic Relations under Classical, Neo-Classical and Relational Contract Law, Northwest University Law Review, 72(b): 854905.

Richardson, R. (1995), Making a Difference, Shoal Bay Press.

Russell (1995), Philosophy and Application - The Contractual Basis of the Employment Contracts Act 1991, New Zealand Business Law Quarterly, 1(3): 145-163.

Street, M. (1993), The Future of the Employment Court and Tribunal: The Labour Party's view. In A Specialist Employment Law Jurisdiction.

Vranken, M. (1988), Specialisation and Labour Courts: a comparative analysis, Comparative Labour Law Journal, 9: 497-525.

Walsh, P. and Ryan, R. (1993), The Making of the Employment Contracts Act. In Harbridge, R. (1993).

Wedderburn, Lord (1988), Labour Law: Autonomy from the Common Law? Comparative Labour Law, 9: 219-252.

Wilson, R. (1993), The Future Structure and Operation of the Employment Court and Employment Tribunal: The Trade Union View. In A Specialist Employment Law Jurisdiction. 